\title{
President and Congress
}

President John Tyler stated that he enjoyed good health, and felt much better since Congress had finally adjourned. (L. A. Godbright, 1869)

At the heart of the Constitution is the separation of power between the President of the United States and Congress. The President has the roles of chief diplomat, Commander-inChief of the Armed Forces and, as head of the executive branch, the responsibility for executing the laws passed by Congress. While the President and Congress were given separate powers and responsibilities, the Founding Fathers also ensured that each would be checked by the other.

\section{Checks and balances}

The President has the power to appoint ambassadors, federal court judges, Supreme Court justices, cabinet members and other top federal posts. Each of these appointments, however, must be confirmed by a vote in the Senate. The Constitution gives the President the power to sign treaties on behalf of the United States, but these must also pass the approval of the Senate (requiring a two-thirds majority). The actions of the 
departments and agencies of the executive branch are subject to scrutiny by Congressional committees who may, in exceptional circumstances, censure officers for their behaviour.

Members of Congress take the role of watchdog seriously. Committees spend a great deal of time questioning and scrutinising the departments and agencies who deal with the policies under the committees' jurisdiction. Many committees also maintain constant, more informal, communications with the agencies and their staff to keep informed as to the successes and failures of existing laws. The exact approach to the oversight role will vary between committees. One criticism of Congress is that too many committees approach oversight with a 'fire-fighter' approach, responding when a problem with the executive branch comes to light, rather than maintaining a more systematic style of surveillance.

When major problems arise, Congressional committees take centre stage in the investigation of what went wrong. Most of the time, such investigations are of little interest to anyone outside of the Washington establishment. Despite this, they can have a real effect. In 1983, the controversial head of the Environmental Protection Agency, Anne Gorsuch, was censured by the House of Representatives for obstructing Congressional oversight by refusing to supply certain documents. Following the censure, Gorsuch resigned. However, when Congress investigates the activities of the President and his key advisers, the process of oversight can capture the attention of the whole nation. In 1986, evidence began to emerge that the Reagan Administration had been covertly selling arms to Iran in exchange for the release of hostages held in Lebanon and then, in direct contravention of the law, passing on the profits of the sales to the 'Contra' rebels fighting in Nicaragua. A series of Congressional investigations discovered not only 
that had profits from the Iranian arm sales been diverted to the Nicaraguan rebels, but that members of the administration had lied to Congress in an attempt at a cover-up and had tried to subvert the process of Congressional oversight. While the President was never directly implicated himself, it did great damage to the remaining years of his Presidency.

\section{Foreign policy}

Most of this book has been concerned with domestic policy; the area in which Congress is usually dominant. Foreign policy, on the other hand, has been historically the domain of the President. Military action often needs immediate decisions, something which a Congress of 535 members is not best suited to take. However, as the example above shows, Congress also has a role to play.

The President is Commander-in-Chief of the Armed Forces and along with the Pentagon and State Department decides on America's military and diplomatic strategies. Like all power in Washington DC, the Constitution ensures that checks and balances exist. The Founding Fathers gave Congress the power to control the funding of the armed forces, to decide when war is declared and, in the case of the Senate, final approval over the appointment of ambassadors. Some of these powers have proven to be limited. Although it is Congress not the President which can officially declare war, the whole notion of declaring war has become outdated. Among others, the Vietnam, Gulf and Afghanistan Wars, were never officially declared. Indeed, despite being involved in numerous conflicts, the United States has not declared war on a nation since World War II. Similarly, while Congress has the power to withdraw funds from any military action it disapproves of, the public support of the armed forces which 
generally greets military action makes Congress wary of being seen to oppose the President. One main criticism of Congress during the Vietnam War was that it shirked its responsibilities by, in the Gulf of Tonkin resolution, giving President Johnson a blank cheque to pursue the war in any way he wished.

However, these limitations do not mean that Congress is impotent in matters of foreign policy. When the Vietnam War started to lose popularity at home, it was Congress which began to reassert itself by limiting the funds available to President Nixon, in an attempt to control his policy. Determined to not repeat the mistakes of the past, Congress passed the War Powers Act in 1973. This Act formalised the role of Congress in checking the President's actions by controlling the funds for military action. Under the War Powers Act, the President on sending troops abroad must, within sixty days, gain formal approval from Congress. If such approval is not forthcoming, he has a further thirty days to withdraw the troops.

The War Powers Act, however, has been criticised for being ineffective. Critics argue that in the modern era many military actions are finished within ninety days, making the approval of Congress irrelevant. Furthermore, in the early stages of a conflict, Congress will be less willing to oppose military action with public support, making the President's task of gaining official sanction straightforward. Indeed, the War Powers Act would have been unlikely to make much difference to the Vietnam War which only began to lose American public support years after troops had been sent into action.

Congress can play a more effective role when foreign policy is not militarily based. Increasingly, economics, trade and actions through the United Nations and NATO are 
becoming as important as troops and bombs. Congress through its Armed Services and Foreign Affairs Committees can begin to have a real impact on policy. The Helms-Burton Act, passed in 1996, imposed stringent economic trade sanctions on the island of Cuba in attempt to isolate the Castro Government. This foreign policy initiative came not from the White House, but from Congress.

\section{Impeachment}

In the most extreme of circumstances, the Constitution gives Congress the power to remove the President from office through the process of impeachment.

On 19 December 1998 President William Jefferson Clinton became only the second President in the history of the United States to be impeached by the House of Representatives. The House voted to impeach on two articles, perjury before the Grand Jury and obstruction of justice, both relating to the President's affair with White House intern Monica Lewinsky and his subsequent denials. They rejected two other charges of perjury in another testimony and abuse of power. In line with the procedures laid out in the Constitution, the Senate then convened to try the President on the impeachment charges. If President Clinton was found guilty by the Senate he would have been the first President to be removed from office by the United States Congress. The trial was presided over by Supreme Court Chief Justice William H. Rhenquist and all 100 Senators were sworn in as the jury. It lasted until 12 February 1999, when the Senate voted to acquit the President of both charges. The Constitution requires a two-thirds majority to reach a guilty verdict, the charge of perjury was rejected with 45 Senators voting guilty, 55 voting to acquit; the charge of obstructing of 
justice saw the Senate tied 50-50, short of the 66 members needed to convict.

The Constitution states that the President may be removed from office through the process of impeachment by the House and conviction by the Senate if he has committed 'high crimes and misdemeanours'. This phrase is open to interpretation and central to the debate surrounding the Clinton impeachment was whether the President's actions could be classed as such. The first President to be impeached by the House was Andrew Johnson in 1868. He survived in office when the Senate fell short of the required two-thirds majority by a single vote. Officially, Johnson's misdemeanour was the sacking of an official in contravention of the then Tenure of Office Act. However, in reality the charges against Johnson were a pretence for a wider political dispute over the role of government in the post-Civil War period of reconstruction. In Johnson's case, the impeachment process was used as a political tool in a battle between President and Congress.

The same allegation was made by the Clinton White House: that the charges against the President were nothing to do with any crime Clinton may have committed but were a partisan attempt by Republicans to damage the President. Hillary Clinton went so far as to describe the charges as part of a 'vast right-wing conspiracy'. Supporters of the President pointed to the fact that the charges were based on a report from independent council Kenneth Starr. Starr had been appointed in 1994 to investigate allegations against the Clintons involving a failed land development deal in Arkansas known as 'Whitewater'. Having failed to find damning evidence in that case, Starr was given permission to widen his enquiries. After examining issues such as the suicide of White House counsel Vince Foster, the firing of staff in the White 
House travel office and invasion of privacy using FBI files, Starr finally found evidence that President Clinton had lied about having sexual relations with Monica Lewinsky. Clinton first denied the affair completely, declaring 'I did not have sexual relations with that woman', but as the evidence mounted he was forced to admit to wrongdoing.

The argument over impeachment centred around the severity of his misdemeanour. Defenders of the President argued that Starr's report was partisan and essentially about Clinton's private life, which did not fall into the category of 'high crimes and misdemeanours'. They pointed to the lurid details included in the report, arguing that they were unnecessary and an attempt to undermine the President. Supporters of impeachment countered that the charges were based on evidence of perjury and obstruction of justice which contradicted the oath the President had taken on assuming office to 'faithfully execute the office of the President of the United States ... and preserve, protect and defend the constitution of the United States'.

As the impeachment process began, it became clear that this would be a largely partisan battle. With some notable exceptions, Republicans were arguing for impeachment and Democrats taking a position against. Such an alignment would give advocates of impeachment enough votes for victory in the House, but would fall short of the two-thirds majority needed in the Senate. Ultimately, it can be argued that Bill Clinton was saved from the ignominy of becoming the first President to be removed from office by the power of public opinion. As the debate on impeachment proceeded, opinion polls showed a marked rise in support for the President. While the majority of people disapproved of the President's behaviour, there was a clear feeling that the public 
did not want to see him removed from office and approved of the job he was doing as President. Rather than the impeachment process harming his public standing, Clinton's approval ratings continued to rise to a high of 70 per cent in February 1999.

\section{Legislative leadership}

The Constitution states that the President of the United States 'shall from time to time give to the Congress Information of the State of the Union, and recommend to their Consideration such Measures as he shall judge necessary and expedient'. The Founding Fathers obviously saw some role for the President in initiating legislation, but in an advisory role. In the early years of the Republic, Congress jealously guarded its position as the sole legislative authority. The President had primacy in affairs of defence and foreign policy, but his role in the legislative process was largely restricted to the power of the veto. Attempts were made by various Presidents to play a larger role in domestic legislation (most notably the 'progressive Presidents' Theodore Roosevelt (1901-9) and Woodrow Wilson (1913-21)), but any advances in the power of the President remained minimal.

The situation changed dramatically with the election of Democrat Franklin D. Roosevelt in 1932. America was suffering from the Great Depression, unemployment reached unprecedented levels and the banking system was in danger of collapse. With no national system of welfare and the states unable to cope, poverty became widespread. President Roosevelt was elected on a promise of using the federal government to address these problems. His 'New Deal' programme, which for the first time established a national 
welfare system, transformed the role of the federal government by involving it in areas previously accepted as the domain of state government. Roosevelt also transformed the power of the presidency. For the first time, the President took the lead in formulating legislation. The first 100 days of the Franklin Roosevelt Presidency witnessed a whirlwind of legislative activity with a raft of legislative proposals produced by the White House and adopted by the Democrat-dominated Congress. Critics charged that during this period Congress failed in its Constitutional responsibilities; rather than act as a deliberative legislative assembly, it became little more than a rubber stamp for the President's programme.

This period of presidential legislative leadership was unprecedented in American history and was never to be repeated again. However, the New Deal set a precedent that allowed future administrations to play a much greater role in the formulation of legislation. All presidential candidates now run for election promising changes in domestic policy, whether it be healthcare, education, welfare or the environment, even though Congress remains the only body which can introduce legislation and pass laws.

The power of the President to get the legislation he desires remains, in the words of Richard Neustadt, the 'power to persuade'. The President has no formal sanctions to compel Congress to consider and pass legislation he supports. Instead he must negotiate, bully and bribe (legally) members of Congress to persuade them to follow his wishes. The White House will work with party and committee leaders in Congress as well as individual members to try and achieve their legislative goals. Common inducements offered to members to persuade them to support the President will often involve a promise of future support for that member's pet project, or 
to ensure that their home state or district will benefit from legislative proposals on other matters.

At the other end of the spectrum, the White House will often attempt to punish members who do not respond to White House pressures. This approach can backfire. In 2001, when Republican Senator Jim Jeffords voted against key provisions of President George W. Bush's economic package he found himself shunned by the White House. He was not invited to the annual 'teacher of the year' award at the White House, despite the fact that education was one of his main interests in the Senate and that the recipient of the award came from his home state of Vermont. The attitude of the Bush Administration towards Jeffords was reportedly influential in finally persuading him to leave the Republican Party, a development which gave the Democrats control of the Senate.

The White House will try and use the knowledge and expertise supplied by its agencies and departments to persuade members to support the administration's policy. However, much will often depend on the ability of the President or his Congressional liaison staff to personally persuade members to give them their support. President Lyndon B. Johnson, who was famous for his persuasive skills while Senate Majority Leader, attempted to use the same techniques from the White House (see Appendix 7.1). President Jimmy Carter had a great deal of difficulty in his relations with Congress, which has been frequently attributed to his inexperience and that of his aides in Washington politics. Carter had previously held office as Governor of Georgia. In contrast President Ronald Reagan, who like Carter only had political experience outside of Washington, benefited from appointing experienced former members of Congress and Capitol Hill staffers to his liaison team. They managed to use their contacts to 
develop relationships and work with Congress with some success.

The President's ability to persuade is inevitably affected by his popularity in the country as a whole. A President with strong public backing for his proposals will be in an advantageous position when attempting to persuade members to lend their support. Nothing focuses the mind of Representatives and Senators more than the prospect of their decisions affecting the level of public support they hold in their district or state. Consequently, in the immediate aftermath of an election victory, a new President is expected to have a 'honeymoon period' when they can use the political capital gained by their election to begin to persuade Congress to pass their election platform into law.

This notion of 'political capital' is central to the power to persuade. The goodwill a new President brings to the position must be used judiciously and can easily be squandered. Two contrasting examples of the use of political capital are the first few months of the presidencies of Bill Clinton and Ronald Reagan. In fairness to Clinton, he arrived at the White House with a less certain mandate from the voters than many of his predecessors. A strong showing by third-party candidate $\mathrm{H}$. Ross Perot ensured that Clinton was elected to the presidency with less than 50 per cent of the popular vote. Nevertheless, any political kudos that Clinton entered the White House with soon diminished following a series of public relations disasters which damaged his public standing. One of the Clinton Administration's first acts was to announce an end to the ban on gay men and women serving in the armed forces. However, the President soon discovered the limitations of Washington politics when he ran into staunch opposition from the military and was forced to compromise on a 'don't 
ask, don't tell' policy which satisfied no one. Soon after, in May of 1993 a scandal erupted when seven workers in the White House travel office were abruptly fired, leading to accusations of abuse of power which triggered a Congressional enquiry. In the same month, President Clinton received a, now infamous, \$200 haircut aboard Air Force One while it sat on a runway at Los Angeles Airport, causing other flights to be delayed. The negative impact on the popularity of the new administration did nothing to help the difficulties President Clinton faced in persuading Congress to pass his legislative agenda.

Clinton's biggest difficulty in providing legislative leadership came with his proposals on extending the scope of federal healthcare. The issue had formed a central plank in his election manifesto, and on arrival in the White House the President placed his wife (now Senator) Hillary Rodham Clinton in charge of a commission to research and formulate the plan. The plan was an important part of the Administration's legislative agenda. Their proposals were presented to Congress in early 1994, but despite Clinton's own party, the Democrats, having a majority in both the House and Senate, the plan died in Congress. The Administration blamed interest groups, specifically medical insurance firms who would lose customers if federal healthcare entitlement was expanded, for pressuring members of Congress to abandon the scheme. There was some truth in this as insurance groups did spend a great deal of money opposing the plan. The Health Insurance Association of America ran a series of television adverts which depicted two average middle-aged Americans 'Harry' and 'Louise' examining Clinton's proposals while discussing its 'hidden costs' and the loss of 'provider choice'. However, the Administration's inexperience in dealing with 
Congress was also a major factor. There was criticism of Hillary Clinton's task force which met behind closed doors before producing a fully formed programme. The scheme itself was said to be complicated and difficult for the average American to understand, let alone support. The lesson to be learned by the Administration was that while the White House can produce and support legislative programmes, Congress holds the sole power to bring such schemes into law. The White House must work with Congress rather than dictate to it.

In contrast, in 1981, the new Reagan Administration used his honeymoon period to its full. The United States was suffering from an economic downturn and Reagan had come to office pledging to reduce the size of government and revitalise the economy. His budget proposed cuts in taxes and most areas of spending (although defence spending was to rise) and the elimination of many federal regulations on businesses. The proposals faced fierce opposition in Congress; members were aware that many of the programmes which faced cuts benefited their constituents. Interest groups also campaigned against cuts in programmes they supported. With such opposition, it looked highly unlikely that President Reagan would succeed in passing much of his budget through Congress. During his Presidency, Reagan became known as the 'Great Communicator' and he used his communication skills to appeal directly to the voters. This strategy, known as 'going public', is often a last resort, but when used successfully can be a potent weapon. He appealed to the public to contact their Senators and Representatives in support of his economic plan and the appeal worked. Faced with a barrage of letters from their voters, Congress relented and passed many of Reagan's key proposals. Speaking to the nation later that year, Reagan 
thanked the public for their support

All the lobbying, the organized demonstrations, and the cries of protest by those whose way of life depends on maintaining government's wasteful ways were no match for your voices, which were heard loud and clear in these marble halls of government. And you made history with your telegrams, your letters, your phone calls and, yes, personal visits to talk to your elected representatives ... Because of what you did, Republicans and Democrats in the Congress came together and passed the most sweeping cutbacks in the history of the Federal budget. ${ }^{1}$

\section{Veto}

If the position of the President is limited in terms of initiating legislation, the Constitution gives a clear role at the other end of the legislative process. Once a bill has passed both the House and Senate, it is sent to the President for his signature. On receipt of the legislation he has three options:

- Sign the bill - passing it into law.

- Do nothing - where, after ten days, it will pass into law without his signature.

- Veto the bill, sending it back to Congress.

If the legislation is vetoed, Congress can pass it into law over the objections of the President if a two-thirds majority is obtained in both the House and Senate. Historically, this has been difficult to achieve with less than 5 per cent of all vetoes being overridden by Congress (see Table 7.1).

The use of the veto should not be viewed as a decision taken in isolation. Throughout the whole legislative process, the White House will be talking with Congressional leaders and the objections of the President will be known before a bill 
Table 7.1 Presidential vetoes (1789-2001)

\begin{tabular}{|c|c|c|c|c|}
\hline President & $\begin{array}{l}\text { Regular } \\
\text { vetoes }\end{array}$ & $\begin{array}{l}\text { Pocket } \\
\text { vetoes* }\end{array}$ & $\begin{array}{l}\text { Total } \\
\text { vetoes }\end{array}$ & $\begin{array}{l}\text { Vetoes } \\
\text { overridden }\end{array}$ \\
\hline George Washington & 2 & - & 2 & - \\
\hline John Adams & - & - & - & - \\
\hline Thomas Jefferson & - & - & - & - \\
\hline James Madison & 5 & 2 & 7 & - \\
\hline James Monroe & 1 & - & 1 & - \\
\hline John Quincy Adams & - & - & - & - \\
\hline Andrew Jackson & 5 & 7 & 12 & - \\
\hline Martin Van Buren & - & 1 & 1 & - \\
\hline William Harrison & - & - & - & - \\
\hline John Tyler & 6 & 4 & 10 & 1 \\
\hline James K. Polk & 2 & 1 & 3 & - \\
\hline Zachary Taylor & - & - & - & - \\
\hline Millard Fillmore & - & - & - & - \\
\hline Franklin Pierce & 9 & - & 9 & 5 \\
\hline James Buchanan & 4 & 3 & 7 & - \\
\hline Abraham Lincoln & 2 & 5 & 7 & - \\
\hline Andrew Johnson & 21 & 8 & 29 & 15 \\
\hline Ulysses S. Grant & 45 & 48 & 93 & 4 \\
\hline Rutherford B. Hayes & 12 & 1 & 13 & 1 \\
\hline James A. Garfield & - & - & - & - \\
\hline Chester A. Arthur & 4 & 8 & 12 & 1 \\
\hline Grover Cleveland & 304 & 110 & 414 & 2 \\
\hline Benjamin Harrison & 19 & 25 & 44 & 1 \\
\hline Grover Cleveland & 42 & 128 & 170 & 5 \\
\hline William McKinley & 6 & 36 & 42 & - \\
\hline Theodore Roosevelt & 42 & 40 & 82 & 1 \\
\hline William H. Taft & 30 & 9 & 39 & 1 \\
\hline Woodrow Wilson & 33 & 11 & 44 & 6 \\
\hline Warren G. Harding & 5 & 1 & 6 & - \\
\hline Calvin Coolidge & 20 & 30 & 50 & 4 \\
\hline Herbert C. Hoover & 21 & 16 & 37 & 3 \\
\hline Franklin D. Roosevelt & 372 & 263 & 635 & 9 \\
\hline Harry S. Truman & 180 & 70 & 250 & 12 \\
\hline
\end{tabular}


Table 7.1 continued

\begin{tabular}{lcccc}
\hline President & $\begin{array}{l}\text { Regular } \\
\text { vetoes }\end{array}$ & $\begin{array}{c}\text { Pocket } \\
\text { vetoes* }\end{array}$ & $\begin{array}{c}\text { Total } \\
\text { vetoes }\end{array}$ & $\begin{array}{l}\text { Vetoes } \\
\text { overridden }\end{array}$ \\
\hline Dwight D. Eisenhower & 73 & 108 & 181 & 2 \\
John F. Kennedy & 12 & 9 & 21 & - \\
Lyndon B. Johnson & 16 & 14 & 30 & - \\
Richard M. Nixon & 26 & 17 & 43 & 7 \\
Gerald R. Ford & 48 & 18 & 66 & 12 \\
James Earl Carter & 13 & 18 & 31 & 2 \\
Ronald Reagan & 39 & 39 & 78 & 9 \\
George Bush & 29 & 15 & 44 & 1 \\
William J. Clinton & 37 & 1 & 38 & 2 \\
George W. Bush & - & - & - & - \\
Total & 1484 & 1066 & 2551 & 106 \\
\hline
\end{tabular}

Pocket vetoes are those used when Congress has adjourned and, as such, cannot be overridden.

reaches his desk. A threat of a veto is one of the tools the White House can use to try to persuade Congress to shape legislation in line with the President's agenda. In 1994, when Congress was debating Bill Clinton's healthcare proposals, the President, afraid that his plan would be watered down, warned Congress 'If you send me legislation that does not guarantee every American private health insurance that can never be taken away, you will force me to take this pen, veto the legislation, and we'll come back here and start all over again'. Such an inflexible approach can backfire as Clinton found when no healthcare bill was reported at all.

Using the veto can be a risky strategy. As an essentially negative tool, by blocking the proposals of Congress the President can appear to be siding with inaction over action. He also faces the possibility of an embarrassing defeat if the 
veto is overridden. Alternatively, opponents of the President in Congress may attempt to force a confrontation with the White House over a veto in the hope of winning the support of the public, especially during an election year. However, as Newt Gingrich discovered in 1995, this strategy can backfire.

The confrontation between the Republican leadership and President Clinton took place over the budget. As is customary, the President had submitted his budget to Congress for consideration at the beginning of the year. There was little prospect of the Republican-dominated Congress accepting Clinton's proposals. The Republicans wanted to see large cuts in federal spending to balance the budget which had been in deficit for many years. The White House was willing to accept some cuts, but objected to the level of reductions in the Republican plans. Such a situation where the White House and Congress disagree on the plans for the budget is not unusual, indeed it is quite common. Normally, to ensure that the Government is funded while the negotiations over the budget are continuing, Congress will pass a continuing resolution to keep programmes afloat until a compromise has been reached. In 1995, however, the Republican Party leadership in Congress ensured that the continuing resolution contained some of the budget cuts that Clinton was opposed to. Since their landslide victory in 1994, the President had been on the back foot and House Speaker Newt Gingrich was looking to push home his advantage. Accordingly, the continuing resolution passed by Congress contained some of the budget cuts for healthcare wanted by the Republican Congress. President Clinton vetoed the measure and, on 14 November 1995, because there was no budget to fund the machinery, the Government partially shutdown. Almost half of the federal employees were sent home from work, national 
monuments and parks closed and new applications for welfare payments could not be processed.

This showdown between the President and Congress was a dangerous play by both sides. The Republican leadership hoped the blame would lie with the White House for blocking their attempts to balance the budget, a goal which seemed to have support in the country. The President argued that he was protecting vital public services from attack by the Republican Party. In his address to the nation announcing the shutdown he laid out his case,

Today, as of noon, almost half of the federal government employees are idle. The government is partially shutting down because Congress has failed to pass the straightforward legislation necessary to keep the government running without imposing sharp hikes in Medicare premiums and deep cuts in education and the environment ... Let me be clear - we must balance the budget. I proposed to Congress a balanced budget, but Congress refused to enact it. Congress has even refused to give me the line-item veto to help me achieve further deficit reduction. But we must balance this budget without resorting to their priorities, without their unwise cuts in Medicare and Medicaid, in education and the environment ... it is my solemn responsibility to stand against a budget plan that is bad for America and to stand up for a balanced budget that is good for America. And that is exactly what I intend to do. ${ }^{2}$

The deadlock lasted until 27 January 1996 with the Government shutting down twice during that period.

In this instance, it was the President's actions which won public support. As the deadlock over the budget continued, opinion polls showed support for the President's position. On 15 November, the second day of the shutdown, 49 per cent of those questioned said they blamed the Republican leadership 
for the crisis, with only 26 per cent blaming Bill Clinton. The President's pitch to the nation seemed to have worked, and he maintained this lead in the opinion polls throughout the deadlock. By 10 January, 57 per cent of voters supported the President, with 36 per cent backing the Republican leadership's stand. ${ }^{3}$ Ultimately, a compromise was reached between the two sides, but one that was viewed more as a victory for Clinton than for the Republicans. The Republican Chairman of the House Budget Committee admitted 'We did the wrong strategy. That's okay. We tried. It didn't work. Now we've got to be smarter'. ${ }^{4}$

In this case President Clinton's use of the veto was a masterstroke. By painting himself as the guardian of public services, he galvanised public support in a way which he had failed to do during the previous three years. With the economy strong and support for the President rising in the opinion polls he proceeded to defeat the Senate Majority Leader Republican Bob Dole in the 1996 election.

\section{Divided government}

The case of the Government shutdown illustrates how conflict can occur when Congress and the presidency are controlled by different parties. Such divided government has been a regular situation in the United States in recent years. In the period 1933-69, the same party controlled both branches of government for all but eight years. Since 1969 however, divided government has become the norm, and in that time the President has faced a Congress with either one or both chambers controlled by the opposing party for all but six years.

Explanations of why divided government has become so 
frequent vary. During the 1980s it was often argued that the parties' reputations meant that voters preferred Republicans to run the White House and Democrats to run Congress; Republicans were seen as stronger on foreign policy (especially in the Cold War terms of being anti-Communist), whereas the Democrats were identified with better social welfare. Consequently, the argument ran, the electors were simply electing the parties to the branch of government which best suited their policies. However, this explanation faced difficulties in the 1990s when between 1995 and 2001 the electorate kept a Democrat in the White House and a Republican majority in Congress. An alternative explanation is that voters engage in 'split-ticket voting' in a deliberate attempt to ensure that one party does not become all powerful. This is often attributed to a general dissatisfaction with both political parties. ${ }^{5}$

It would be logical to assume that the White House and Congress would be able to co-operate more easily when they are controlled by the same party. Indeed, there is evidence that when one party controls both branches of government, the President is more successful in passing his proposals and less likely to use the veto than under divided government. ${ }^{6}$ However, the difference should not be overstated. As Bill Clinton found with his healthcare plan, unified government is no guarantor of Presidential success. Indeed, David Mayhew has gone so far as to argue that 'it does not seem to make all that much difference whether party control of the American Government happens to be unified or divided'.

\section{Summary}

The Constitution of the United States ensures that each power given to the President or Congress is checked by the other 
branch of government. Since 1933, domestic policy has been characterised by co-operation and competition between the White House and Congress. Despite this, Congress remains the only body which can pass federal laws. Congress acts as a watchdog over the executive branch, with the ultimate power to remove the President if he is found guilty of 'high crimes and misdemeanours'. In turn, the President has the ability to veto legislation passed by Congress, although if two-thirds of the House and Senate agree, the veto can be overturned. Foreign policy is usually the domain of the White House, but Congress has proved able to play a role in this area also.

\section{Appendix: the Johnson treatment}

On 23 January, 1964 the Senate Finance Committee was giving final consideration to a tax cut bill backed by President Johnson. On that morning, Senator Everett Dirksen surprised the White House by proposing an amendment which would repeal taxes on a wide range of luxury goods. The committee passed the amendment. The new cuts, it was estimated, would cost the treasury over $\$ 400$ million, and threatened to endanger the success of both the bill and Johnson's budget. The president needed the committee to reconsider the amendment and reject it. Johnson took over the campaign to persuade committee members himself. While he trod carefully with senior committee members, he was not afraid to try and strong-arm others. What follows is a transcript of a telephone conversation between President Johnson and fellow Democrat and committee member Senator Abraham Ribicoff, who had supported and contributed to Dirksen's amendment.

Johnson: Hey Abe. Can't you go with us on this excise thing and let us get a bill? Goddamn it, you need to vote with me once in a while - just one time.

Ribicoff: Mr President, look. I made a commitment. President ... 
Let me say this - the Treasury Department is reaping the whirlwind.

Johnson: I know it. I know it. We were ready to report this bill, and now we've got it just good and screwed up, and the Democrats are going to be a miserable failure in the eyes of the country. Now why can't you all meet at two o'clock, ad let's leave this excise like we had it before you met this morning?

Ribicoff: Well, I don't know how you're going to keep it - the thing was overwhelming.

Johnson: No, it's not. No. Clint Anderson is going to help us. Hartke will help us. And if you'll help us, we'll have it over. And I'll appreciate it and I'll remember it. Help me one way or the other.

Ribicoff: You know, just one word, Mr President -

Johnson: You've had these problems, executive, and you know we've had that damn bill there since September. And every day it's costing us $\$ 30$ million in consumer income, every single day. Ribicoff: One of my problems is one of the amendments in there is something in my home state that's already been announced.

Johnson: I know it, but every one of them has got it in there, my friend. But God almighty, I think about the problems I've had. And when you wanted to go on that committee, I just stood up and said, 'By God, it's going to be.'

Now, I just want one vote, and I want to get that bill out of there, and I've got to have it, Abe. And you've had problems. You've been an executive. And you can find a way to help me.

They've asked me to call you 40 times this year and I've never done it. But this time, when it means $\$ 400$ or $\$ 500$ million - this is going to be a whole motion to leave all the excises as they were before Williams and them got mad on the oil thing. And don't let John Williams and Everett Dirksen screw me this way.

Ribicoff: Let me see how I can save my face. I've got a problem Johnson: Don't you worry about saving your face. Your face is in damn good shape, and it's going to be better when I get with you. I'll save your face. [Ribicoff chuckles.] You save my face this afternoon, and I'll save your face tomorrow.

Ribicoff: Well some time, I would really like to talk to you. 
Johnson: You can do it any hour, any hour. I've had 56 days in this job, and they've been the most miserable 56 I've ever had.

Ribicoff: You're doing good, sir.

Johnson: And my people are going [in] opposite directions. And now damn Harry Byrd goes one way and he says cut your damn budget, and I'll help you get your bill out. He called me yesterday and said it would be reported tomorrow. I thought it was all settled.

Ribicoff: You're doing great, Mr President. Honest to God. You're doing so great it isn't even -

Johnson: Will you go in there and help me this afternoon?

Ribicoff: Let me try. Let me see how I can work it out.

Johnson: You just work it out. Now don't say how. I don't give a damn about the details. I just want you to work it out. Will you? Ribicoff: I'll do my - OK, Mr President.

Johnson: Bye.

Ribicoff: Bye.

Later that day the Senate Finance Committee voted 9 to 8 to reject the Dirksen amendment. The tax cut bill was reported by 12 to 5 .

Source: Presidential Recordings Project, Miller Center.

\section{Notes}

1 R. Reagan, Address to the Nation on Federal Tax Reduction Legislation, July 27, 1981, Public Papers of the President.

2 William J. Clinton, Address to the Nation, November 14, 1995, Public Papers of the President.

3 Washington Post-ABC News poll, 10 Jan 1996.

4 CNN.com, Third federal shutdown averted, 27 January 1996.

5 M. Fiorina, Divided Government (Boston Allyn \& Bacon, 1996), ch 4.

6 S. S. Smith, The American Congress (Boston: Houghton Mifflin, 1999), ch 3.

7 D. R. Mayhew, Divided We Govern: Party Control, Lawmaking and Investigations, 1946-1990 (New Haven: Yale University Press, 1991), p. 198. 